\title{
Why is Southern African canine babesiosis so virulent? An evolutionary perspective
}

\author{
Barend L Penzhorn
}

\begin{abstract}
Canine babesiosis is a common, highly virulent disease in Southern Africa with even pups and juveniles being severely affected. This contrasts with bovine babesiosis, for example, where host, parasite and vector co-evolved and young animals develop immunity after infection without showing clinical signs. Babesia rossi, the main causative organism of canine babesiosis in sub-Saharan Africa, was first described from a side-striped jackal (Canis adustus) in Kenya. Although data are meagre, there is evidence that indigenous African canids, such as jackals and wild dogs (Lycaon pictus), can harbour the parasite without showing untoward effects. Dogs are not indigenous to Africa. The vast majority of dogs presented at veterinary facilities in South Africa represent recently introduced European, Asian or American breeds. The contention is that B. rossi is a new challenge to which these dogs have not adapted. With intensive treatment of clinical cases, natural selection is effectively negated and the status quo will probably be maintained indefinitely. It is postulated that Babesia vogeli, which frequently results in unapparent infections or mild manifestations in dogs, represents or is closely related to the ancestral form of the canine parasite, possibly originating from wolves (Canis lupus).
\end{abstract}

\section{Introduction}

Babesiosis is one of the most important canine diseases in South Africa. Countrywide, babesiosis is diagnosed in around $10 \%$ of dogs presented to veterinary practices [1]. At the Onderstepoort Veterinary Academic Hospital on the outskirts of Pretoria, South Africa, around 12\% of sick dogs presented are diagnosed with babesiosis, and around 31\% of these are admitted for more intensive treatment [2]. Canine babesiosis, referred to as "malignant jaundice or bilious fever", was first reported from the Cape Colony in 1893 [3]. Early reports alluded to the virulent nature of the disease in South Africa [4-6], which differed from the manifestation in other parts of the world. Working with a South African isolate, Nutall and Hadwen (1909) commented that the parasites used in experiments in Italy must have been much less virulent than theirs $[7,8]$. Furthermore, dogs that survived infection with a French isolate were fully susceptible to the South African one, prompting Laveran \& Nattan-Larrier to conclude in 1913 that the African

\footnotetext{
Correspondence: banie.penzhorn@up.ac.za
}

Department of Veterinary Tropical Diseases, Faculty of Veterinary Science, University of Pretoria, Private Bag X04, Onderstepoort, 0110, Republic of South Africa babesia of dogs, if not a separate species, was at least a variety distinct from the French one $[9,10]$.

It was soon evident that isolates from different geographic regions were vector-specific. South African isolates were transmitted by Haemaphysalis elliptica, previously misidentified as Haemaphysalis leachi [4,11]. Isolates from North Africa, the Middle East and India were transmitted by Rhipicephalus sanguineus, while those from Southern Europe were transmitted by Dermacentor reticulatus [12-14]. Later research confirmed this vector-specificity $[15,16]$.

It is rather curious, therefore, that generally no notice was taken of this clear evidence of distinct biological differences between region-specific isolates. Until 20-odd years ago, it was generally accepted that babesiosis in dogs was caused by two species: a large piroplasm, Babesia canis, and a small one, Babesia gibsoni. Although the parasites had some characteristics in common, the disease manifestations were distinct. In 1989, Uilenberg et al. [17] reminded the scientific community that three distinct taxa were generally lumped under the "large" Babesia: B. canis (sensu stricto) [18], transmitted by Dermacentor reticulatus, occurring in Southern Europe, but seemingly spreading northwards $[19,20]$; the cosmopolitan B. vogeli [21], transmitted by Rhipicephalus sanguineus; and B. rossi [22], 
transmitted by Haemaphysalis elliptica, restricted to subSaharan Africa. It was subsequently demonstrated that these three taxa can de differentiated molecularly as well [23]. A fourth, as yet unnamed, large Babesia has since been reported from dogs in the USA [24].

Pre-1990 literature on canine babesiosis should therefore be considered cautiously, as the actual causative agent may be in doubt. Although $B$. vogeli has been recorded in South Africa, it seems to be relatively rare and the large body of literature on canine babesiosis, especially concerning pathogenesis and clinical manifestation, can be safely attributed to $B$. rossi $[25,26]$. Similarly, most references from Europe probably refer to $B$. canis (sensu stricto). Elsewhere, B. vogeli would probably be the causative agent. Persisting in merely referring to "canine babesiosis" without specifying the causative agent, is scientifically unsound.

The "small" piroplasm does not refer to a single species either. At least five taxa have been described: Babesia gibsoni (sensu stricto) [27], Babesia conradae [28], a Babesia microti-like organism [29], Theileria annae [30] and an unnamed Theileria species [31].

\section{Clinical manifestation of $B$. rossi infection}

The earliest scientific descriptions of canine babesiosis in South Africa are of a highly virulent disease [4-6]. Subsequent intensive study has borne this out.

Babesia rossi causes peracute and acute disease, the clinical signs including pale mucous membranes, depression, tachycardia, tachypnoea, anorexia, weakness, splenomegaly and fever [32]. The clinical signs are attributed to tissue hypoxia resulting from anaemia and a concomitant systemic inflammatory response syndrome caused by marked cytokine release [33]. The severe form of the disease is characterised by haemolytic anaemia and severe acid-base derangements [34], with secondary multiple organ failure and complications such as acute renal failure, hepatopathy with marked icterus, hypoglycaemia [35], acute respiratory distress syndrome, cerebral pathology and additional immune-mediated erythrocyte destruction [32,36]. Mortality is around $12 \%$ [32]. A feature of the disease is that, in contrast to babesiosis in other domestic species, pups and immature dogs are also badly affected [32,37].

In contrast, $B$. vogeli infection in mature dogs is often unapparent or results in moderate clinical signs only, with the parasitaemia appearing to be low [32]. Although subclinical infections are common in adult dogs, pups tend to present with marked anaemia [38]. Babesia canis infection results in a more varied pathogenicity, intermediate between the other two species [32].

The question arises, therefore: why is $B$. rossi more virulent than the other two taxa? It is contended that, from an evolutionary perspective, domestic dogs have not had sufficient time to adapt to this parasite. Let us consider some examples where parasite and host apparently evolved together.

\section{Endemic stability in bovine babesiosis}

Babesia bovis and Babesia bigemina are major causative agents of bovine babesiosis, especially in tropical and subtropical regions, where they are thought to have evolved [39]. Although some other hosts can be infected, usually artificially, both species are primary parasites of cattle [39]. Similarly, the vectors involved, at least in the Old World, are the bovine-specific Rhipicephalus (Boophilus) microplus and Rhipicephalus (Boophilus) decoloratus [40]. It can be concluded, therefore, that co-evolution occurred between host, vector and parasite. This is further borne out by the fact that all domestic cattle have an inherent capacity to cope with infection and to develop immunity to disease without showing clinical signs [41]. This capacity is age-specific, however, and has generally disappeared by the time a calf is one year of age. Under natural conditions, i.e. where no vector control is practised, the parasites would circulate freely in the cattle population. For the first few months of life, calves would be passively protected by maternal antibody ingested with colostrum. Once this protection has waned, calves becoming naturally infected will develop immunity without showing overt clinical signs. The net result is a high prevalence of infection, but a low occurrence of clinical disease. This situation is referred to as endemic stability. This feature is utilised to the advantage of livestock owners: calves vaccinated between 3 and 9 months of age usually develop solid immunity, without showing overt clinical signs [42].

\section{Babesiosis in wildlife}

Although not as well studied as in cattle, there is mounting evidence that a similar situation exists in various wildlife species. For instance, black rhinoceroses (Diceros bicornis) have been found to harbour Babesia bicornis without showing any clinical signs of infection [43]. If black rhinoceroses are stressed, however, either through human intervention such as capture or under natural conditions such as drought, clinical babesiosis may ensue [43-45]. This is attributed to immunosuppression due to stress.

Similarly, a free-ranging sable antelope (Hippotragus niger) that had been captured in the low-lying, warm, bushveld region of north-eastern South Africa and transferred to the Johannesburg Zoo, at an altitude of $1800 \mathrm{~m}$, in mid-winter succumbed to babesiosis within a few weeks [46]. It can be assumed that this individual had been a subclinical carrier of the infection. Subsequently, 
sable antelopes raised in captivity in Europe and therefore never exposed to infection, were translocated to a game ranch in South Africa, where they contracted babesiosis when housed in an enclosure adjoining one in which wild-caught local sable antelopes were held [47].

A further example is Babesia leo, which is prevalent in free-ranging lion populations $[48,49]$. The death of the famous lioness "Elsa" due to babesiosis after being released in the wild was probably stress-induced [50]. This lioness had repeatedly been severely mauled by the resident lion population [51].

This seems to suggest that a state of equilibrium, i.e. endemic stability, exists, at least in the three examples given. Individuals are able to cope with infection without developing overt clinical signs. This may be dependent on exposure at a young age, as suggested by the captive-bred sable antelopes being fully susceptible to infection, although stress caused by translocation may also have played a role.

How does this pertain to Babesia infections in canids?

\section{Babesia rossi infection in African canids}

Babesia rossi was first described from a side-striped jackal (Canis adustus) in Kenya, and was subsequently also found in blood and organ smears from a jackal pup $[22,52]$. The literature on babesiosis in indigenous African canids is meagre. The first attempt to infect two black-backed jackals (Canis mesomelas) was deemed unsuccessful, as the animals remained clinically normal and subinoculation of their blood to susceptible dogs yielded no results [53]. Subsequently, black-backed jackals artificially infected by subinoculation of blood from infected domestic dogs developed parasitaemia but no overt clinical signs $[54,55]$. Although fatal clinical babesiosis was reported in an African wild dog (Lycaon pictus) pup in the Johannesburg Zoo [56], experimental subinoculation of blood from infected domestic dogs did not precipitate clinical signs in wild dogs [55]. In a large breeding centre, 17/227 (7.0\%) of wild dog blood specimens were positive for $B$. rossi [57]. Clinical babesiosis had never been observed in this population, and the infected wild dogs seemed to harbour B. rossi with no untoward effect. Trophozoites presumed to be Babesia canis (probably B. rossi) were seen in $2 / 29$ (6.9\%) of wild dog blood smears from the Kruger National Park, South Africa [58], while a single piroplasm, possibly a Babesia sp., was seen on a blood smear from 1/16 wild dogs in Serengeti ecosystem, Tanzania [59]. This scant evidence fits the general picture, however, and would seem to suggest that indigenous African canids are able to cope with $B$. rossi infection and become subclinical carriers of the parasite.

Haemaphysalis elliptica, the only known vector of $B$. rossi, is common on South Africa domestic dogs, especially those in peri-urban or rural areas. It is rarely recovered from indigenous canids, but has been reported from captive and free-ranging wild dogs $[58,60]$. It is much more commonly found on indigenous felids [61-64]. It may be significant that the largest number of $H$. elliptica recovered from an indigenous canid was from a side-striped jackal, the host from which $B$. rossi was originally described [61]. Clinical babesiosis is diagnosed in around $12 \%$ of dogs presented at the Onderstepoort Veterinary Academic Hospital, where $H$. elliptica is the most common tick on dogs, while babesiosis was uncommon at another veterinary clinic, situated in a densely populated urban area around $20 \mathrm{~km}$ away, where $R$. sanguineus was the most common dog tick recovered $[62,65]$.

In a recent paper on pathogens of domestic and wild canids in Brazil, antibodies to Babesia (no species mentioned) were found in domestic dogs only, and not in a small sample of maned wolves (Chrysocyon brachyurus), crab-eating foxes (Cerdocyon thous) and hoary foxes (Lycalopex vetulus) [66]. This may suggest that South American canids are not susceptible to the various Babesia species associated with domestic dogs.

\section{Dogs not indigenous to Africa}

With the exception of domestic cats (descended from wild cats (Felis silvestris), which range throughout Africa and Eurasia) [67] and donkeys [descended from African wild asses (Equus asinus)] [68], all domestic animals are exotic to Africa. Domestic dogs have descended from wolves (Canis lupus), whose natural distribution is the Palearctic and Nearctic regions [69]. Recent mtDNA data suggest that dogs were domesticated south of the Yangtze River in China, from numerous wolves, less than 16,300 years ago [70].

There is ample evidence that natural selection is facilitating the ability of domestic animals to cope with various sub-Saharan vector-borne pathogens, provided that sufficient time has elapsed since their introduction to the continent. Although not fully resistant, West African Ndama cattle and certain goat and sheep breeds are regarded as tolerant to Trypanosoma infections transmitted by tsetse flies (Glossina species) [71]. Local breeds of Bos indicus (Zebu) cattle, e.g. Nguni and Sanga, exhibit a measure of inherited resistance to heartwater (Ehrlichia ruminantium infection, transmitted by Amblyomma ticks), probably acquired through millennia of natural selection [72]. This resistance does not prevent infection becoming established, but reduces the severity of clinical disease [72]. Theileria parva, primarily transmitted by Rhipicephalus appendiculatus, is a natural parasite of African buffaloes which is so virulent to cattle that the host usually succumbs before the 
parasite can complete its life cycle. This is the manifestation usually encountered in South Africa, where clinical manifestation is called Corridor Disease [73]. In East Africa, where natural selection has resulted in a certain degree of tolerance developing in cattle, the parasite can complete its life cycle in the host and cattle-to-cattle transmission is the norm. This manifestation is called East Coast fever [74].

Although not indigenous to Africa, genetic characterisation of the Africanis breed, which is endemic in rural areas in South Africa, supports archaeological evidence that dogs were introduced from the Middle East thousands of years ago [75]. A crucial part of the puzzle, which is still lacking, is whether natural selection in Africanis dogs has rendered them resistant or at least tolerant of $B$. rossi.

Most dogs presented to veterinary facilities in South Africa are breeds originating in Europe, Asia and the Americas [37]. As such, they are confronted by an alien parasite, $B$. rossi, and are fully susceptible.

\section{Conclusion}

As $B$. vogeli is the least virulent of the species, I contend that it has had the longest association with domestic dogs. It is tempting to speculate that $B$. vogeli, or a closely related form, occurs in wolves, the ancestors of domestic dogs. Unfortunately, information on haemoparasites of wolves appears to be lacking. A further interesting phenomenon is that Rhipicephalus sanguineus, the vector of $B$. vogeli, feeds primarily on domestic dogs [76]. R. sanguineus has been recorded from captive wolves [77], but seemingly not from free-ranging wolves, although the literature is scanty. Could this imply that $R$. sanguineus has evolved as a dog-specific species during the thousands of years since the domestication of the dog?

It is difficult to speculate where $B$. canis fits into the picture. The widely spread golden jackal (Canis aureus) does occur in south-eastern Europe and could possibly be a contender for original host, but this is pure conjecture, as data on haemoparasites and ticks associated with this host are lacking.

It can be confidently stated, though, that $B$. rossi is a natural parasite of indigenous African canids. The vast majority of affected domestic dogs are fairly recent introductions to South Africa that have not yet evolved mechanisms to cope with this infection. As clinically affected dogs are usually treated and generally recover, natural selection is effectively negated and the status quo will probably be maintained indefinitely.

\section{Acknowledgements}

Publication of the CVBD6 thematic series has been sponsored by Bayer Animal Health $\mathrm{GmbH}$.
Declaration of competing interests

The author declares that they have no competing interests.

Received: 14 January 2011 Accepted: 13 April 2011

Published: 13 April 2011

\section{References}

1. Collett MG: Survey of canine babesiosis in South Africa. I S Afr Vet Assoc 2001, 71(3):180-186.

2. Shakespeare AS: The incidence of canine babesiosis amongst sick dogs presented to the Onderstepoort Veterinary Academic Hospital. I S Afr Vet Assoc 1995, 66(4):247-250.

3. Hutcheon D: Diseases amongst dogs. Malignant jaundice or bilious fever of the dog. Agric J Cape Good Hope 1893, 6:476-477.

4. Lounsbury $\mathrm{CH}$ : Transmission of malignant jaundice of the dog by a species of tick. Agric J Cape Good Hope 1901, 19:714-724.

5. Lounsbury $\mathrm{CH}$ : Ticks and malignant jaundice of the dog. J Comp Path Therap 1904, 17:113-129.

6. Theiler A: Beitrag zur Frage der Immunität bei der Piroplasmosis des Hundes. Zbl Bakt Parasitenk Inf (Erste Abt/Orig) 1904, 37:401-405.

7. Gonder R: Atoxylversuche bei der Piroplasmose der Hunde. Arb K Gesundgheitsamte 1908, 27:301-309.

8. Nuttall GHF, Hadwen S: The successful drug treatment of canine piroplasmosis, together with observation upon the effect of drugs on Piroplasma canis. Parasitology 1909, 2:156-191.

9. Ciuca A: A propos de l'immunité du chien vis-à-vis de la piroplasmose canine (Babesiose canine). Bull Soc Path Exot 1913, 6:499-501.

10. Laveran A, Nattan-Larrier : Piroplasmoses canines d'Europe et d'Afrique. Ann Inst Pasteur 1913, 27:701-717.

11. Apanaskevich DA, Horak IG, Camicas JL: Redescription of Haemaphysalis (Rhipistoma) elliptica (Koch, 1844), an old taxon of the Haemaphysalis (Rhipistoma) leachi group from East and southern Africa, and of Haemaphysalis (Rhipistoma) leachi (Audouin, 1826) (Ixodida, Ixodidae). Onderstepoort J Vet Res 2007, 74:181-208.

12. Christophers SR: Preliminary note of development of Piroplasma canis in the tick. Br Med J 1907, 76-78.

13. Brumpt E: Transmission de la piroplasmose canine tunisienne par le Rhipicephalus sanguineus. Bull Soc Path Exot 1919, 12:757-764.

14. Brumpt E: Transmission de la piroplasmose canine française par le Dermacentor reticulatus. Embolies parasitaires dans les capillaires de I'encéphale. Bull Soc Path Exot 1919, 12:651-664.

15. Nieschultz O, Wawo-Roentoe FK: Einige Versuche mit Piroplasma canis und Rhipicephalus sanguineus. Z Infektionskr Parasit Krankh Hyg Haustiere 1931, 40:60-63.

16. Regendanz P, Reichenow E: Beitrag zur Uebertragungsweise von Babesia canis durch Zecken. Zbl Bakt Parasitenk Inf (Erste Abt/Orig) 1932, 124:471-478.

17. Uilenberg G, Franssen FFJ, Perie M, Spanjer AAM: Three groups of Babesia canis distinguished and a proposal for nomenclature. Vet Q 1989, 11:33-40.

18. Piana GP, Galli-Valerio B: Su di un' infezione del cane con parasiti endoglobulari. Mod Zooiatr 1895, 6:163-169.

19. Matjila PT, Nijhof AM, Taoufik A, Houwers D, Teske E, Penzhorn BL, de Lange T, Jongejan F: Autochthonous canine babesiosis in The Netherlands. Vet Parasit 2005, 131:23-29.

20. Oines O, Storli K, Brun-Hansen H: First case of babesiosis caused by Babesia canis canis in a dog from Norway. Vet Parasit 2010, 171:350-353.

21. Reichenow E: Ueber die Entwicklung von Theileria parva, dem Erreger des Küstenfiebers der Rinder, in Rhipicephalus appendiculatus. Zbl Bakt Parasitenk Inf (Erste Abt/Orig) 1937, 140:223-226.

22. Nuttall GHF: On haematozoa occurring in wild animals in Africa. Piroplasma rossi n. sp. and Haemogregarina canis adusti n.sp. found in the jackal. Parasitology 1910, 3:108-116.

23. Carret C, Walas F, Carcy B, Grande N, Précigout É, Moubri K, Schetters TP, Gorenflot A: Babesia canis canis, Babesia canis vogeli, Babesia canis rossi: Differentiation of the three subspecies by a restricted fragment length polymorphism analysis on amplified small subunit ribosomal RNA genes. J Eukaryot Microbiol 1999, 46:298-303.

24. Birkenheuer AJ, Neel J, Ruslander DS, Levy MG, Breitschwerdt EB: Detection and molecular characterization of a novel large Babesia species in a dog. Vet Parasit 2004, 124:151-160. 
25. Matjla PT, Penzhorn BL, Bekker CPJ, Nijhof AM, Jongejan F: First record of Babesia canis vogeli in domestic dogs in South Africa. Vet Parasit 2004, 122:119-125.

26. Matjila PT, Leisewitz AL, Jongejan F, Penzhorn BL: Molecular detection of tick-borne protozoal and ehrlichial infections in domestic dogs in South Africa. Vet Parasit 2008, 155:152-157.

27. Patton WS: Preliminary report on a new piroplasm (Piroplasma gibsoni $\mathrm{n}$. sp.) found in the blood of the hounds of the Madras hunt and subsequently discovered in the blood of the jackal, Canis aureus. Bull Soc Path Exot 1910, 3:274-280.

28. Kjemtrup AM, Wainwright K, Miller M, Penzhorn BL, Carreno RA: Babesia conradae, sp. nov., a small canine Babesia identified in California. Vet Parasit 2006, 138:103-111.

29. Zahler M, Rinder H, Schein E, Gothe R: Detection of a new pathogenic Babesia microti-like species in dogs. Vet Parasit 2000, 89:241-248.

30. Camacho AT, Pallas E, Gestal JJ, Guitian FJ, Olmeda AS, Goethert HK, Telford SR: Infection of dogs in north-west Spain with a Babesia microtilike agent. Vet Rec 2001, 149:552-555.

31. Matjila PT, Leisewitz AL, Oosthuizen MC, Jongejan F, Penzhorn BL: Detection of a Theileria species in dogs in South Africa. Vet Parasit 2008, 157:34-40.

32. Schoeman JP: Canine babesiosis. Onderstepoort J Vet Res 2009, 76:59-66.

33. Taboada J, Lobetti RG: Babesiosis. In Infectious diseases of the dog and cat. 3 edition. Edited by: Greene CE. St Louis: Saunders Elsevier; 2006:722-736.

34. Leisewitz AL, Jacobson LS, de Morais HS, Reyers F: The mixed acid-base disturbances of severe canine babesiosis. J Vet Int Med 2001, 15:445-452.

35. Keller N, Jacobson LS, Nel M, de Clerq M, Thompson PN, Schoeman JP: Prevalence and risk factors of hypoglycemia in virulent canine babesiosis. J Vet Int Med 2004, 18:265-270.

36. Jacobson LS: The South African form of severe and complicated canine babesiosis: clinical advances 1994-2004. Vet Parasit 2006, 138:126-139.

37. van Zyl M: An epidemiological investigation into hospitalised cases of canine babesiosis. In Proceedings of a symposium on canine babesiosis. Edited by: Lewis BD, Jacobson LS. Onderstepoort: Faculty of Veterinary Science, University of Pretoria; 1995:42-43.

38. Irwin PJ, Hutchinson GW: Clinical and pathological findings of Babesia infection in dogs. Austr Vet J 1991, 68:204-209.

39. De Vos AJ, de Waal DT, Jackson LA: Bovine babesiosis. In Infectious Diseases of Livestock. Volume 1.. 2 edition. Edited by: Coetzer JAW, Tustin RC. Cape Town: Oxford University Press; 2004:406-424.

40. Norval RAI, Horak IG: Vectors: Ticks. In Infectious Diseases of Livestock. Volume 1.. 2 edition. Edited by: Coetzer JAW, Tustin RC. Cape Town: Oxford University Press; 2004:3-42.

41. Trueman KF, Blight GW: The effect of age on resistance of cattle to Babesia bovis. Austr Vet J 1978, 54:301-305.

42. De Vos AJ: Epidemiology and control of bovine babesiosis in South Africa. J S Afr Vet Assoc 1979, 50:357-362.

43. Nijhof A, Penzhorn BL, Lynen G, Mollel JO, Bekker C, Jongejan F: Babesia bicornis sp. $\mathrm{n}$. and Theileria bicornis sp. $\mathrm{n}$.: Tick-borne parasites associated with mortality in the black rhinoceros (Diceros bicornis). J Clin Microbiol 2003, 41:2249-2254.

44. McCullogh B, Achard PL: Mortalities associated with capture, translocation, trade and exhibition of black rhinoceroses. Int Zoo Yb 1960, 9:184-195.

45. Mugera GM, Wandera JG: Degenerative myopathies in East African domestic and wild animals. Vet Rec 1967, 80:410-413.

46. Martinaglia G: Red-water (babesiosis) in a sable antelope. J S Afr Vet Med Assoc 1930, 1(4):41-42.

47. McInnes EF, Stewart CG, Penzhorn BL, Meltzer DGA: An outbreak of babesiosis in imported sable antelope (Hippotragus niger). I S Afr Vet Assoc 1991, 62:30-32.

48. Penzhorn BL, Kjemtrup AE, López-Rebollar LM, Conrad PA: Babesia leo n. sp. from lions in the Kruger National Park, South Africa, and its relation to other small piroplasms. J Parasit 2001, 87:681-685.

49. Bosman AM, Venter EH, Penzhorn BL: Occurrence of Babesia felis and Babesia leo in domestic cats and various wild felid species in Southern Africa, based on reverse line blot analysis. Vet Parasit 2007, 144:33-38.

50. Barnett SF, Brocklesby DW: Some piroplasms of wild animals. Symp Zool Soc Lond 1968, 24:159-176.

51. Adamson J: Living free London: Collins \& Harvill; 1962.

52. Nuttall GHF: Note on Rossiella rossi (Nuttall, 1910) occurring in the jackal in British East Africa. Parasitology 1912, 5:61-64.
53. Nuttall GHF, Graham-Smith GS: Note on attempts to infect the fox and the jackal with Piroplasma canis. Parasitology 1909, 2:211-214.

54. Neitz WO, Steyn HP: The transmission of Babesia canis (Piana and GalliValerio, 1895) to the black-backed jackal [Thos mesomelas (Schreber)], with a discussion of the classification of the piroplasms of the Canidae. J S Afr Vet Med Assoc 1947, 18:1-12.

55. van Heerden J: The transmission of Babesia canis to the wild dog (Lycaon pictus) (Temminck) and black-backed jackal Canis mesomelas (Schreber). J S Afr Vet Assoc 1980, 18:119-120.

56. Colly LP, Nesbit JW: Fatal acute babesiosis in a juvenile wild dog. J S Afr Vet Assoc 1992, 63:36-38.

57. Matjila PT, Leisewitz AL, Jongejan F, Bertschinger HJ, Penzhorn BL: Molecular detection of Babesia rossi and Hepatozoon sp. in African wild dogs (Lycaon pictus) in South Africa. Vet Parasit 2008, 157:123-127.

58. Van Heerden J, Mills MGL, van Vuuren MJ, Kelly PJ, Dreyer MJ: An investigation into the health status and diseases of wild dogs (Lycaon pictus) in the Kruger National Park. J S Afr Vet Assoc 1995, 66:18-27.

59. Peirce MA, Laurenson MK, Gascoyne SC: Hepatozoonosis in cheetahs and wild dogs in the Serengeti ecosystem. Afr J Ecol 1995, 33:273-275.

60. Van Heerden J: Disease and mortality of captive hunting dogs Lycaon pictus. S Afr J Wildl Res 1986, 16:7-11.

61. Horak IG, Jacot-Guillarmod A, Moolman LC, de Vos V: Parasites of domestic and wild animals in South Africa. XXI. Ixodid ticks on domestic dogs and on wild carnivores. Onderstepoort J Vet Res 1987, 54:573-580.

62. Horak IG: Ixodid ticks collected at the Faculty of Veterinary Science, Onderstepoort, from dogs diagnosed with Babesia canis infection. J S Afr Vet Assoc 1995, 66:170-171.

63. Horak IG, Braack LEO, Fourie L, Walker JB: Parasites of domestic and wild animals in South Africa. XXXVIII. Ixodid ticks collected from 23 wild carnivore species. Onderstepoort J Vet Res 2000, 67:239-250.

64. Horak IG, Heyne H, Donkin EF: Parasites of domestic and wild animals in South Africa. XLVIII. Ticks (Acari: Ixodidae) infesting domestic cats and wild felids in Southern Africa. Onderstepoort J Vet Res 2010, 77(1), Art. \#3, 7 pages.

65. Bryson NR, Horak IG, Höhn EW, Louw JP: Ectoparasites of dogs belonging to people in resource-poor communities in north West Province, South Africa. J S Afr Vet Assoc 2000, 71:175-179.

66. Curi NHDA, Araújo AS, Campos FS, Lobato ZIP, Gennari SM, Marvulo MFV, Silva JCR, Talamoni SA: Wild canids, domestic dogs and their pathogens in Southeast Brazil: disease threats for canid conservation. Biodivers Conserv 2010, 19:3513-3524.

67. Driscoll CA, Menotti-Raymond M, Roca AL, Hupe K, Johnson WE, Geffen E, Harley EH, Delibes M, Pontier D, Kitchener AC, Yamaguchi N, O'Brien SJ, Macdonald DW: The Near Eastern origin of cat domestication. Science, NY 2007, 317:519-523.

68. Kimura B, Marshall FB, Chen SY, Rosenbom S, Moehlman PD, Tuross N, Sabin RC, Peters J, Barich B, Yohannes H, Kebede F, Teclai R, Beja-Pereira A, Mulligan CJ: Ancient DNA from Nubian and Somali wild ass provides insights into donkey ancestry and domestication. Proc R Soc B-Biol Sci 2011, 278:50-57.

69. Mech LD: Canis lupus. Mammalian Species 1974, 37:1-6.

70. Pang JF, Kluetsch C, Zou XJ, Zhang AB, Luo LY, Angleby H, Ardalan A, Ekstrom C, Skollermo A, Lundeberg J, Matsumura S, Leitner T, Zhang YP, Savolainen P: mtDNA data indicate a single origin for dogs south of Yangtze River, less than 16,300 years ago, from numerous wolves. Mol Biol Evol 2009, 26:2849-2864.

71. Connor RJ, Van den Bossche P: African animal trypanosomoses. In Infectious Diseases of Livestock. Volume 1.. 2 edition. Edited by: Coetzer JAW, Tustin RC. Cape Town: Oxford University Press; 2004:251-296.

72. Uilenberg G: Heartwater (Cowdria ruminantium infection): current status. Adv Vet Sci Comp Med 1983, 27:427-480.

73. Lawrence JA, Perry BD, Williamson SM: Corridor disease. In Infectious Diseases of Livestock. Volume 1.. 2 edition. Edited by: Coetzer JAW, Tustin RC Cape Town: Oxford University Press; 2004:468-471.

74. Lawrence JA, Perry BD, Williamson SM: East Coast Fever. In Infectious Diseases of Livestock. Volume 1.. 2 edition. Edited by: Coetzer JAW, Tustin RC. Cape Town: Oxford University Press; 2004:448-467.

75. Greyling LM, Grobler PJ, Van der Bank HF, Kotze A: Genetic characterisation of a domestic dog Canis familiaris breed endemic to South African rural areas. Acta Theriol 2004, 49:369-382.

76. Dantes-Torres F: The brown dog tick, Rhipicepalus sanguineus (Latreille, 1806) (Acari: Ixodidae): From taxonomy to control. Vet Parasit 2008, 152:172-185. 
77. Harvey JM, Simpson CF, Gaskin JM, Sameck JH: Ehrlichiosis in wolves, dogs and wolf-dog crosses. J Am Vet Med Assoc 1979, 175:901-905.

doi:10.1186/1756-3305-4-51

Cite this article as: Penzhorn: Why is Southern African canine babesiosis

so virulent? An evolutionary perspective. Parasites \& Vectors 2011 4:51

Submit your next manuscript to BioMed Central and take full advantage of:

- Convenient online submission

- Thorough peer review

- No space constraints or color figure charges

- Immediate publication on acceptance

- Inclusion in PubMed, CAS, Scopus and Google Scholar

- Research which is freely available for redistribution

Submit your manuscript at 